\title{
Why Chief Justice Roy MoORe ANd THE Alabama SUPREME COURT JUST MADE THE CASE FOR SAME-SEX MARRIAGE
}

\author{
Adam Lamparello* \\ "Justice is conscience, not a personal conscience but the conscience of the whole of \\ humanity." \\ Alexander Solzhenitsyn
}

\section{INTRODUCTION}

The Alabama Court of the Judiciary should remove Roy Moore from the Supreme Court of Alabama for a second and final time. ${ }^{1}$ Over ten years after being ousted from the Alabama Supreme Court, ${ }^{2}$ Chief Justice Moore is embroiled in yet another controversy that involves disregarding the federal courts and creating chaos in the legal system. Moore's behavior, not to mention the ruling by the Alabama Supreme Court in Ex parte State of Alabama (Ex parte Alabama), ${ }^{3}$ is akin to a bad movie sequel that should have never been made and rightfully bombs at the box office.

To be fair, Chief Justice Moore abstained in Ex parte Alabama, where the Alabama Supreme Court held, by an 8-1 margin that it was not bound by a federal district court's decision invalidating Alabama's same-sex marriage ban, and that same-sex marriage bans did not violate the United States Constitution. ${ }^{4}$ To reach this result, the court took the extraordinary and rare step of exercising original jurisdiction, manufacturing standing by unilaterally realigning the parties, and issuing a writ of mandamus that prohibited probate judges throughout Alabama from issuing marriage licenses to

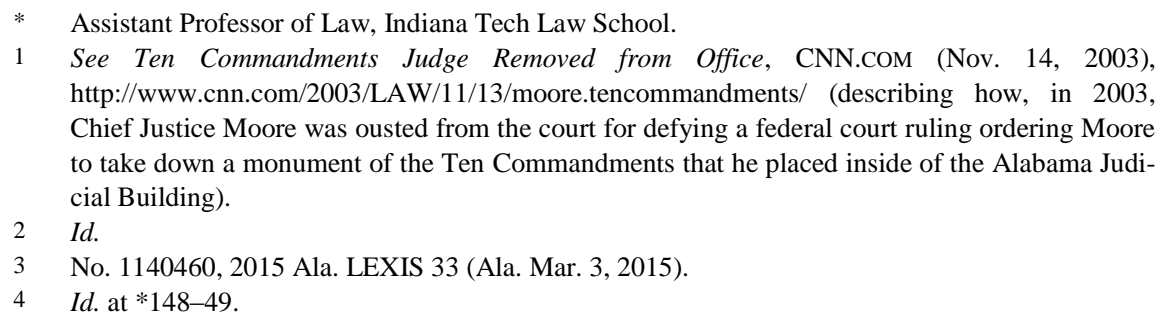


same-sex couples. ${ }^{5}$ The Court's ruling ignored the fact that the Eleventh Circuit Court of Appeals and United States Supreme Court had already declined to review the case, and made no mention of the fact that the U.S. Supreme Court will decide by June the fate of same-sex marriage bans nationwide. In other words, there was no justification whatsoever to issue the writ except to deny same-sex couples a right that thirty-seven states-and twenty-six state and federal courts - have already recognized. ${ }^{6}$ Put bluntly, the Alabama Supreme Court's Houdini-esque reasoning made Griswold v. Connecticut ${ }^{7}$ and Roe v. Wade ${ }^{8}$ seem like an exercise in old school originalism 9 and validated the claim that "judicial activism" is not a "liberal" phenomenon, but a reaction to "a decision you don't like." 10

Why did the Alabama Supreme Court go to all this trouble? To keep on life support a law that twenty-six state and federal courts have held furthers no rational state interest whatsoever and that reflects unadulterated animus against same-sex couples. ${ }^{11}$ As discussed below, the primary arguments advanced in favor of restricting marriage to opposite sex couplesprocreation and child-rearing - are about as laughable as Roy Moore's attempt to defy a ruling by the federal courts in 2003, ordering Moore's Ten Commandments Monument be removed from the Alabama Judicial Building. ${ }^{12}$ If anything, the Alabama Supreme Court's recent decision harkens back to a dark period in Alabama's history, when then-Governor George Wallace defied a federal court order in a symbolic attempt to stop desegregation. $^{13}$

$5 \quad I d$. at *40 ("It is clear that no other court in this State has the jurisdiction to provide the relief necessary in this most unusual of cases. There is a need for immediate, uniform relief among all the probate judges of this State, and no circuit court has jurisdiction over any probate judge outside its territorial jurisdiction.").

6 See 37 States with Legal Gay Marriage and 13 States with Same-Sex Marriage Bans, ProCon.ORG (Mar. 4, 2015, 9:47:40 AM), http://gaymarriage.procon.org/view.resource.php? resourceID $=004857$.

7381 U.S. 479 (1965) (invalidating a law prohibiting the use of contraception for the purpose of preventing conception).

8410 U.S. 13 (1973) (holding the implied right of privacy in the Fourteenth Amendment's Due Process Clause encompassed a woman's right to terminate a pregnancy before viability).

9 See, e.g., Ilya Somin, The Borkean Dilemma: Robert Bork and the Tension Between Originalism and Democracy, 80 CHI. L. Rev. Dialogue 243 (2013).

10 Cheryl K. Chumley, Sonia Sotomayor: Judicial Activism is Not Real-It's Called a Ruling You Don't Like, WASH. Times (Feb. 3, 2015), http://www.washingtontimes.com/news/2015/feb/3/ sonia-sotomayor-judicial-activisms-not-real-its-ca/.

11 See PROCON.ORG, supra note 6.

12 See Thou Shall Not Defy a Federal Court Order, COMmONwEALTH Times (Sept. 4, 2003), http:// www.commonwealthtimes.org/2003/09/04/thou-shall-not-defy-a-federal-court-order/.

13 See Alan Blinder, Judge Defies Gay Marriage Law, N.Y. TimES, Feb. 9, 2015, at A1, available at http://www.nytimes.com/2015/02/09/us/gay-marriage-set-to-begin-in-alabama-amidprotest.html?_r=0 (stating that Chief Justice Moore's conduct "has deep resonance in a place where a governor, George Wallace, stood in a doorway of the University of Alabama in 1963 in an unsuccessful bid to block its federally ordered integration"). 
Technically, the Alabama Supreme Court did not err in disregarding the federal court's order. ${ }^{14}$ However, the fact that it did so is troubling. Even more troubling are the legal gymnastics that the court engaged in to achieve what even a casual observer knew would be a decision reaffirming traditional marriage. Ironically, the court's decision-and the legal jujitsu it employed-makes the best possible case for same-sex marriage. Among other things, the decision threatens to disrupt the country's delicate system of cooperative federalism, undermine the rule of law, and tar the judiciary with the taint of arbitrariness. ${ }^{15}$ Make no mistake: this case is not about states' rights. It is about the integrity of the judicial system, which rises and falls on the public's perception that judges are impartial and objective decision-makers, not self-interested actors who view the law as a vehicle to impose their policy predilections on citizens.

Importantly, should the U.S. Supreme Court rule in favor of same-sex marriage, its decision should rest on equal protection principles, not a nebulous and non-textual concept of liberty. ${ }^{16}$ Such reasoning will ground this right in the text, or at least a reasonable interpretation thereof, and minimize the inevitable, albeit hollow, cries of 'activism' that will accompany such a decision. After all, federal courts must intervene sometimes to protect the rule of law, preserve democratic governance, and safeguard equal rights, particularly when Alabama judges ignore a federal court ruling or decide to impose the death penalty despite a jury's recommendation of life imprisonment. ${ }^{17}$

In addition, Roy Moore should be removed from the Alabama Supreme Court for the second and last time. Moore recently went so far as to suggest that he would ignore the Supremacy Clause and not respect a U.S. Su-

14 See, e.g., Ronald J. Krotoszynski, Alabama's Dangerous Definiance, N.Y. TIMES, Mar. 6, 2015, at A29, available at http://www.nytimes.com/2015/03/06/opinion/alabamas-dangerous-defiance. $\mathrm{html}$ ?_r $=0$ ("Because state and federal courts operate on entirely separate tracks, the state court's position that it need not follow lower federal court rulings is technically correct.").

15 See id. ("Yet if our judicial system is to function smoothly, both [state and federal] court systems must, from time to time, refrain from exercising their legal discretion.... If State Supreme Courts followed the Alabama Supreme Court's lead, a system of dual courts simply would not work.").

16 See U.S. ConST. amend. XIV, § 1 (“All persons born or naturalized in the United States, and subject to the jurisdiction thereof, are citizens of the United States and of the state wherein they reside. No state shall make or enforce any law which shall abridge the privileges or immunities of citizens of the United States; nor shall any state deprive any person of life, liberty, or property, without due process of law; nor deny to any person within its jurisdiction the equal protection of the laws.").

17 See, e.g., Page Williams, Double Jeopardy: In Alabama, A Judge Can Override a Jury that Spares a Murderer from the Death Penalty, NEW YORKER, Nov. 17, 2014, available at http:// www.newyorker.com/magazine/2014/11/17/double-jeopardy-3. 
preme Court ruling in favor of same-sex marriage. ${ }^{18}$ That statement brings back memories of Governor Wallace's infamous stand at the schoolhouse door. At least Wallace had a change of heart later in life and distanced himself from his "segregation now, segregation tomorrow, and segregation forever" speech. ${ }^{19}$ Moore has not learned his lesson. But he will soon, when the U.S. Supreme Court rules that same-sex marriage bans violate the Equal Protection Clause. If, as Moore has suggested, he would not follow a ruling by the Supreme Court in favor of same-sex marriage, the Alabama Court of the Judiciary should dismiss him from the bench immediately. This article summarizes the Alabama Supreme Court's 148-page decision and explains why it was motivated by politics and ideology, not law and justice. The decision represents animus toward same-sex couples and a continuation of Alabama's long history of drawing arbitrary classifications that enshrine discrimination into the law.

\section{The AlabAma Supreme Court's Decision CirCumVented ESTABLISHED PRINCIPLES OF FEDERALISM}

By way of background, in Searcy v. Strange,${ }^{20}$ the United States District Court for the Southern District of Alabama held that Alabama's same-sex marriage ban violated the Equal Protection and Due Process Clauses of the Fourteenth Amendment to the United States Constitution. ${ }^{21}$ Shortly after declaring the ban unconstitutional, a probate judge in Mobile, Alabama denied a marriage license to a same-sex couple. ${ }^{22}$ In response, the district court entered a preliminary injunction and enjoined the Alabama Attorney General and "all his officers, agents, servants, and employees, and others in active concert or participation with any of them," 23 from enforcing the prohibition on same-sex marriage.

Alabama's probate judges, however, believed that they were obligated to enforce Alabama state law. ${ }^{24}$ In a subsequent order, the district court acknowledged that the probate judges were not technically obligated to follow the ruling, but noted that if clerks of court declined to follow the rul-

18 See Jeremy Diamond, Chief Alabama Judge Would Defy Supreme Court in Gay Marriage Ruling, CNN.COM (Feb. 12, 2015), http://www.cnn.com/2015/02/12/politics/ray-moore-alabamagay-marraige-supreme-court-slavery/.

19 Carl T. Rowan, The Rehabilitation of George Wallace, WASH. Post, Sept. 5, 1991, at A21, available at http://www.washingtonpost.com/wp-srv/politics/daily/sept98/wallace090591.htm.

20 No. 14-0208-CG-N, 2015 U.S. Dist. LEXIS 7776 (S.D. Ala. Jan. 23, 2015).

21 See id.; see also Judgment Entry for the Plaintiffs, Searcy, 2015 U.S. Dist. LEXIS 7776, available at http://www.gpo.gov/fdsys/pkg/USCOURTS-alsd-1_14-cv-00208/pdf/USCOURTS-alsd-1_ 14-cv-00208-4.pdf (holding that Alabama's same-sex marriage ban violated the Due Process Clause and the Equal Protection Clause of the Fourteenth Amendment).

22 See Ex parte Alabama, No. 1140460, 2015 Ala. LEXIS 33, at *8 (Ala. Mar. 3, 2015).

$23 I d$. at $* 5$.

$24 \quad I d$. 
ing, another injunction would be issued. ${ }^{25}$ The district court stayed the initial order pending the Attorney General's appeal to the Eleventh Circuit Court of Appeals and the United States Supreme Court. ${ }^{26}$ Both courts declined to hear the case, prompting the district court to lift the stay. ${ }^{27}$ One day before the stay was lifted, Chief Justice Roy Moore entered an order, stating that the district court's order and injunction were not binding on probate judges and prohibiting probate judges from issuing same-sex marriage licenses. ${ }^{28}$

Thereafter, the Alabama Policy Institute and Alabama Citizens Action Program filed a petition with the Alabama Supreme Court seeking a writ of mandamus to prohibit Alabama's probate judges from issuing marriage licenses to same-sex couples. ${ }^{29}$ The Alabama Supreme Court ordered briefing, including on the issues of whether the court had subject matter jurisdiction and whether the plaintiffs had standing. ${ }^{30}$ The court also realigned one of the parties - a probate judge - who had refused to issue a same-sex marriage license, and collectively referred to the plaintiffs as relators. ${ }^{31}$ The relators argued that Alabama probate judges have a ministerial duty to comply with Alabama law, thus rendering the district court's order unenforceable against those judges. The respondents - probate judges who had followed the district court's order-argued that the writ should not be issued because it would require the Alabama Supreme Court to determine whether the same-sex marriage ban violated the United States Constitution, a matter over which the court did not have jurisdiction. ${ }^{32}$

The Alabama Supreme Court disagreed and issued the writ. To achieve this result, the court made the extraordinary decision to exercise original jurisdiction, bypassing the typical requirement that cases proceed through the lower state courts before undergoing review by the Alabama Supreme Court. ${ }^{33}$ The court's reasoning was based on the well-settled, but rarely invoked, principle that state courts do not have to follow lower federal court orders, and are only bound by decisions of the United States Supreme Court. $^{34}$ The court was technically correct, but it made no sense for the court to exercise jurisdiction because, among other things, the U.S. Su-

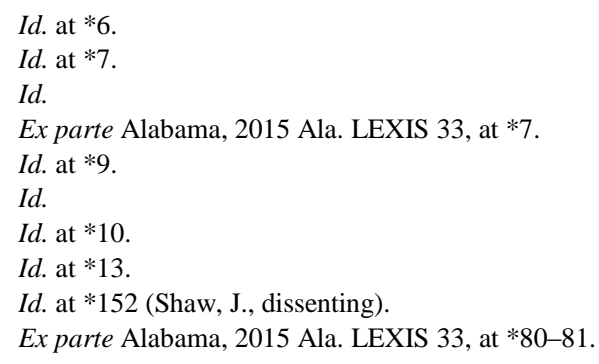


preme Court had already granted certiorari in DeBoer v. Snyder $r^{35}$ and will determine the fate of same-sex marriage bans within months.

Upon granting original jurisdiction, the court reviewed the case on an expedited basis and predictably held that probate judges' ministerial duties are governed by Alabama law, which may be superseded only by the United States Constitution. ${ }^{36}$ Since bans on same-sex marriage did not, in the court's view, violate the Constitution, probate judges were not permitted to issue marriage licenses to same sex couples. ${ }^{37}$ As discussed below, the court's reasoning was hopelessly flawed regarding: (1) the exercise of original jurisdiction; (2) the determination that the relators had standing; and (3) the decision that same-sex marriage bans did not violate the Equal Protection Clause.

\section{A. The Court's Decision to Exercise Original Jurisdiction Threatens to Undermine Principles of Federalism}

The Alabama Supreme Court invoked Section 140(b) of the Alabama Constitution, which states that the Supreme Court "shall have original jurisdiction ... to issue such remedial writs or orders as may be necessary to give it general supervision and control of courts of inferior jurisdiction." 38 The court acknowledged that the writ is only used "in extreme cases and under unusual circumstances," ${ }^{39}$ and where "justice cannot otherwise be done," 40 but deemed this case sufficiently exigent to justify its issuance. The Court noted that throughout history, marriage had been defined as the union of a man and a woman, and that redefining marriage to include opposite-sex couples would result in a seismic shift in Alabama law. ${ }^{41}$ In so holding, the court relied heavily on its decision in Ex parte Alabama Textile Products Corp. ${ }^{42}$ where it exercised original jurisdiction because the lower state court did not have the power to provide sufficient relief "in time to prevent the consummation of the alleged wrong." 43

Justice Greg Shaw, the lone dissenter, exposed the infirmities in this reasoning. Shaw explained that the statutory scheme, which permitted "remedial and individual writs as are necessary to give to it [the Alabama Supreme Court] a general superintendence and control of courts of inferior

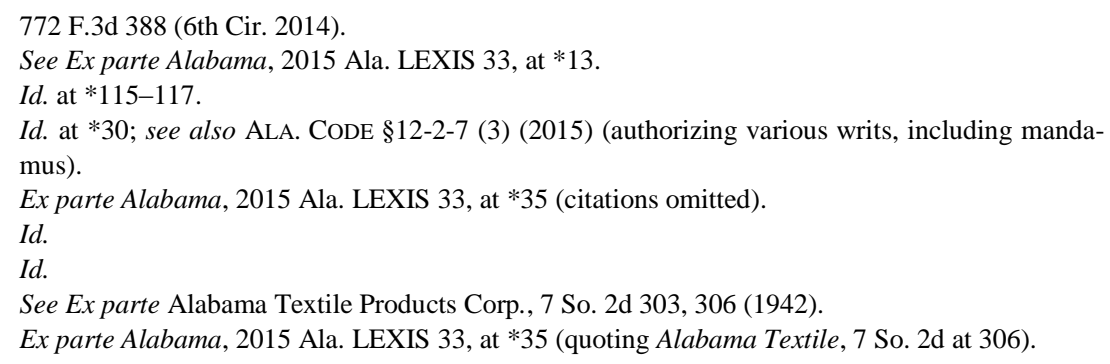


jurisdiction." ${ }^{44}$ The power to issue original writs, however, does not encompass original jurisdiction, but instead refers to writs that "review interlocutory decisions of the lower courts." 45 As Justice Shaw explained, this approach was consistent with the Alabama Supreme Court's common practice to hear petitions "challenging a lower court's decision in a pending case."46 Since the Eleventh Circuit and U.S. Supreme Court had already declined to hear this matter, the district court's order was final and prohibited the court from exercising original jurisdiction.

Furthermore, "[a]dvising a probate judge how to issue government marriage licenses is not 'superintendence and control' of an inferior court's performance of a judicial function," ${ }^{47}$ but rather "instructing a State official acting in a nonjudicial capacity." 48 Simply put, "the [probate] court has no judicial power to issue a marriage license, ${ }^{\prime 49}$ but instead is something that "the legislature has instructed that probate judges 'may' do." Alabama Textile was distinguishable because it held that the Supreme Court could "supervise persons and bodies clothed with judicial power" and review the judicial action "of an inferior tribunal vested with judicial or quasi-judicial power." 52 Consequently, Alabama Textile did not provide the Alabama Supreme Court with "original jurisdiction to review the nonjudicial functions of probate judges." 53

Alabama Textile is distinguishable for another reason: the United States Supreme Court had not already granted certiorari to pass on the identical question that, in Ex parte Alabama, the Alabama Supreme Court deemed worthy of original jurisdiction. It made no sense for the Alabama Supreme Court to exercise jurisdiction because the U.S. Supreme Court decision will-within months - fully resolve the question and, depending on the result, redress any perceived harm that would result from issuing samesex marriage licenses. If the Supreme Court invalidates same-sex marriage bans nationwide, then Alabama will be in the same position as when the federal district court issued its order, except that this time the Supremacy Clause will, absent a revolt by Chief Justice Roy Moore, prohibit Alabama from disregarding federal law. ${ }^{54}$ If the Supreme Court holds that states

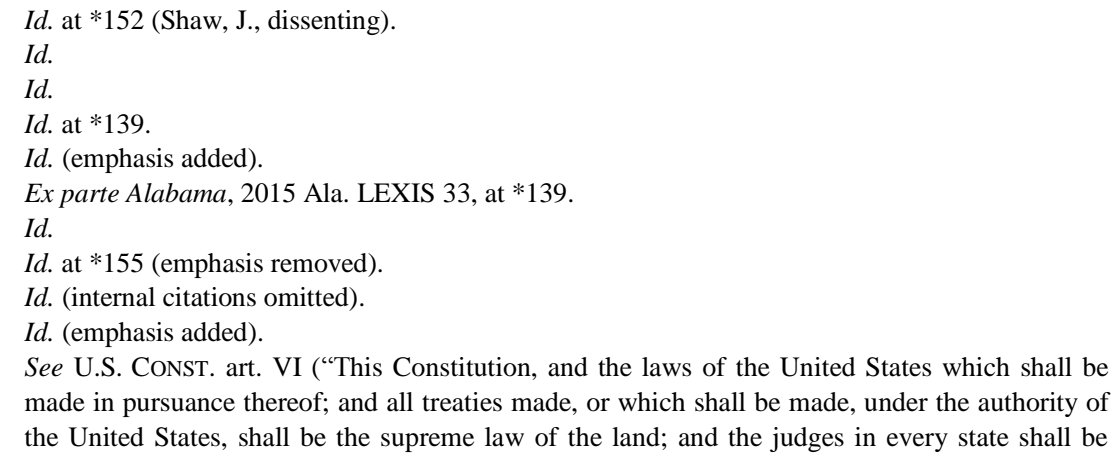
made in pursuance thereof; and all treaties made, or which shall be made, under the authority of the United States, shall be the supreme law of the land; and the judges in every state shall be 
need not recognize same-sex marriage, then all marriage licenses that were issued after the district court's ruling, but before the Supreme Court's decision will be null and void. As such, the Alabama Supreme Court's writ does nothing but preserve the status quo until a higher court tells Alabama what it must do or can lawfully undo.

Simply put, the justification for issuing a writ of mandamus was anything but extraordinary. This is not a situation where "for special reasons complete justice cannot otherwise be done," 55 or where intervention is necessary to prevent "a denial of justice." 56 If anything, a denial of justice is precisely what it causes. The court's decision denies to same-sex couples a right that state and federal courts across the country have recognized, and that the Eleventh Circuit and U.S. Supreme Court, in refusing to review the case, suggests is imminent.

\section{B. The Court Manufactured Standing Because No Citizens Were Actually Harmed by the District Court's Ruling}

To "afford full relief and do complete justice," 57 the Alabama Supreme Court was required to consider the constitutionality of same-sex marriage bans. The obvious question is, who was harmed by the district court's decision? Children? Opposite-sex couples? Alabama's understanding of state sovereignty? After all, the Alabama Supreme Court had no authority to hear this case unless a party could show that it had standing to challenge the district court's decision.

The standing doctrine requires a litigant to demonstrate an actual, concrete, and particularized injury, a causal connection between the injury and alleged wrongful conduct, and the likelihood that the injury will be redressed by a favorable decision. ${ }^{58}$ Even though Alabama law is coextensive with federal standing doctrine, ${ }^{59}$ the Alabama Supreme Court managed to wiggle out of this problem by relying on a case from Indiana that invoked the "public standing doctrine," a seldom-used exception to the standing requirement. ${ }^{60}$ This doctrine applies when public rather than private rights are at issue, and does not require the litigant to demonstrate an actual injury or an interest that differs from the general public. ${ }^{61}$ Given that

bound thereby, anything in the Constitution or laws of any State to the contrary notwithstanding.").

55 Ex parte Alabama, 2015 Ala. LEXIS 33, at *40.

$56 \quad I d$.

57 Id. at $* 42$.

58 Lujan v. Defenders of Wildlife, 504 U.S. 555, 560-61 (1992).

59 See Ex parte Alabama, 2015 Ala. LEXIS 33, at *45 (quoting Lujan, 504 U.S. at 560-61).

60 See id. at *48 (quoting State ex rel. Cittadine v. Ind. Dep't of Transp., 790 N.E. 978, 983 (Ind. 2003)).

$61 \quad$ See id. at $* 47$. 
the court had unilaterally realigned the parties to include as a plaintiff a probate judge who had refused to issue same-sex marriage licenses, the court was able to conclude both that standing existed and that the mandamus was warranted to "procure the enforcement of a public duty." 62 The court also relied on the related concept of "public interest standing," which allows courts to issue writs of mandamus "in matters of great public interest ... to compel an officer to do his or her duty." 63 In such cases, the "only interest necessary is that of the people at large." ${ }^{\prime 64}$

Once again, the dissent exposed the flaws in this reasoning. Justice Shaw explained that, although "citizens can sometimes sue in the name of the State to compel a public officer to perform a legal duty in which the public has an interest," 65 they cannot do so when the issue relates to "the sovereign rights of the State." ${ }^{\prime \prime}$ Undoubtedly, the authority of Alabama to limit the definition of marriage to opposite-sex couples implicated its sovereign powers, and, therefore, barred citizens from suing on the state's behalf. The Alabama Supreme Court's conclusion to the contrary prompted the dissent to state that "[t]his Court is applying a different rule in this case."67 Indeed, if the typical standing requirements had applied - as they should have-none of the parties would have had standing. The relators did not suffer an injury "in a personal and individual way" 68 that distinguished them from members of the public who shared their views about same-sex marriage. Of course, the fact that the court had to go to such great lengths - adding a plaintiff and relying on a rarely used exception to the typical standing requirements-shows how desperate the court was to prevent same-sex couples from marrying.

Furthermore, the notion that there was an urgent public interest in enforcing a public duty rested on the assumption that same-sex marriage was a threat to the public interest, and that the district court's order did not create a new duty requiring probate judges to issue same-sex marriages, particularly after the Eleventh Circuit and U.S. Supreme Court denied Alabama's appeals. Perhaps most telling was that the Alabama Supreme Court had to distinguish its own precedent, which established that, where the sovereign rights of the state are implicated, writs of mandamus can only issue if the Attorney General, not a probate judge, is the relator. ${ }^{69}$ The only exception to this rule is where another public official has an interest that is

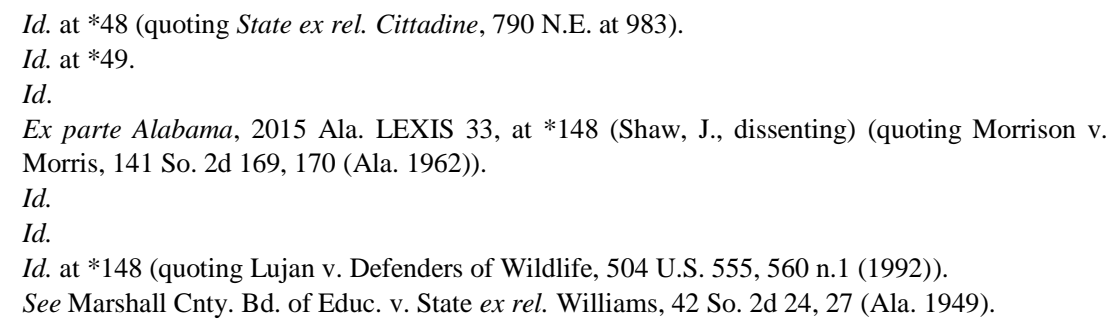


"peculiar" and thus different from the Attorney General, such that standing would be justified. The Alabama Supreme Court held that the probate judge had a "peculiar interest" $" 0$ because the judge was directly responsible for issuing same-sex marriage licenses, although it held earlier in the opinion that the probate judges' interest was no different than the general public. This is a textbook example of manipulating the law to achieve a preordained outcome.

\section{The Court's Rationale for Upholding Same-Sex Marriage Bans- Procreation and Child Rearing-Are Meritless}

\section{The Court Unwisely Disregarded the Federal District Court's Order}

The Alabama Supreme Court relied on the principle that "state courts may interpret the United States Constitution independently from, and even contrary to, federal courts." 71 The court emphasized that "we defer only to the holdings of the United States Supreme Court and our own interpretations of federal law." ${ }^{72}$ Consequently, the federal district court's order was binding only if the Alabama Supreme Court agreed with its conclusion that same-sex marriage bans violated the United States Constitution. As discussed below, the Alabama Supreme Court's answer to that question was certainly no.

The court was technically correct that state courts are not bound by the decisions of federal district courts or circuit courts of appeals. In the substantial majority of cases, however, state courts will adhere to federal court rulings, particularly where such rulings are affirmed (or review is denied) by the circuit court of appeals and certiorari is denied by the United States Supreme Court. ${ }^{73}$ This is precisely what the Alabama Supreme Court should have done, particularly because, as the dissent noted, the plaintiffs "have not asked this Court to rule on the constitutionality of Alabama's marriage-protection laws."74

To depart from this practice and exercise original jurisdiction for this decision, creates chaos. Imagine if the Alabama Supreme Court's view of

Ex parte Alabama, 2015 Ala. LEXIS 33, at *73.

Id. at $* 76$.

Id. (citing Preferred Risk Mut. Ins. Co. v. Ryan, 589 So. 2d 165, 167 n.2 (Ala. 1991) (holding that only decisions of the United States Supreme Court are binding on state courts).

73 See generally, Amanda Frost, Inferiority Complex: Should State Courts Follow Lower Federal Court Precedent on the Meaning of Federal Law?, 68 VAND. L. REV. 53 (2015) (discussing the problems that would result if state courts frequently refused to follow decisions of the lower federal courts).

74 Ex parte Alabama, 2015 Ala. LEXIS 33, at *150 (Shaw, J., dissenting). 
constitutional federalism were followed by all states. It would mean that no decision from a federal district court or circuit court of appeals would be binding on a state. Since the U.S. Supreme Court only hears a tiny fraction of cases each year, Alabama's approach would, as a practical matter, give the states authority to ignore rights deemed fundamental by federal district and appellate courts under the U.S. Constitution. As such, absent the U.S. Supreme Court or Congress's recognition of a fundamental right, each state's constitution, and interpretations thereof by state court judges, would be equal, if not superior, to the federal Constitution and give states nearly unchecked authority to create or disparage fundamental rights. This would reduce the Supremacy Clause to a legal fiction, tremendous incongruity regarding the nature and scope of fundamental rights would result, and the Full Faith and Credit Clause would be written out of existence. The incorporation doctrine would mean very little because, in most cases, state courts would have sole authority to interpret the federal Constitution and thereby define rights and powers in any manner they pleased.

For example, the Supreme Court of States A and B could arrive at opposite conclusions regarding whether the "separate but equal" doctrine violates the Equal Protection Clause. This would not only subject African Americans to state-sanctioned discrimination, but it would force some African Americans to flee the state to escape segregation. The only remedy for African Americans would be through the U.S. Supreme Court because the political and democratic process in states that adopt "separate but equal" would be all but non-existent for African Americans. Perhaps the Supreme Court or Congress would intervene in such a case, but neither the Court nor Congress would be able to repair the myriad ways in which states might interpret either the federal or state constitutions to deny basic freedoms that are "implicit in the concept of ordered liberty." "75

The practical effect is that the Ninth Amendment, which states that the Constitution should not be interpreted to deny or disparage other rights $r e$ tained by the people, ${ }^{76}$ would be a near-nullity. Some states, like Alabama, could refuse to recognize any rights other than those contained in the Bill of Rights, and construe the Bill of Rights so narrowly that basic freedoms attendant to those rights would be denied. The point, of course, is that the Alabama Supreme Court's decision to exercise jurisdiction is entirely inconsistent with our constitutional scheme because it undermines principles of cooperative federalism governance. It results in an unworkable and unreasonably narrow interpretation of the Supremacy Clause, and gives states

75 See, e.g., Washington v. Glucksberg, 521 U.S. 702, 721 (1997) (citation omitted) (holding the right to assisted suicide was not protected by the Due Process Clause of the Fourteenth Amendment).

76 See U.S. CONST. amend. IX ("The enumeration in the Constitution, of certain rights, shall not be construed to deny or disparage others retained by the people."). 
the right to nullify the rulings of all federal courts but one. That is not a prescription for states' rights or state sovereignty. It is an indirect way of circumventing express and implied rights, particularly those that are not enumerated.

The greatest irony of Alabama's approach is that it may actually lead to more control by the federal government. If Alabama's model prevailed across the country, Congress might act more aggressively to pass legislation exerting broad control in various areas of governance, and the Supreme Court might not only defer to such legislation, but may also create broad and categorical rules guaranteeing positive and negative rights against arbitrary deprivation by the state.

Also, it would throw the concept of citizenry, and the relationship between states and the federal government, into turmoil. For example, if federal courts recognized a right to pre-viability abortion, but some states did not, then citizens living in a state that prohibited abortion would possess the right in name only. In this way, state and federal citizenry would no longer be co-extensive, as state citizenry would deprive citizens of the actual enjoyment of those rights. Put differently, individuals would no longer be citizens of the several states or even of the United States.

\section{The Interests in Procreation and Child Rearing Do Not Justify Same-Sex Marriage Bans}

The Alabama Supreme Court relied on the state's interest in procreation and child rearing to hold that same-sex marriage bans further rational state interests, even though dozens of federal and state courts have exposed the fallacies in this argument. To begin with, the court held that same-sex marriage bans are not subject to strict or intermediate scrutiny because sexual orientation is not a suspect class. ${ }^{77}$ Additionally, the Court rejected the proposition that same-sex marriage bans discriminate on the basis of gender because "[a]11 men and women are equally entitled to enter the institution of marriage." 78 A similar argument was made in Loving $v$. Virginia, ${ }^{79}$ where the United States Supreme Court invalidated state bans on interracial marriage. ${ }^{80}$ In that case, attorneys for the state of Virginia argued that the ban did not violate the Equal Protection Clause because the ban applied equally to citizens of all races. ${ }^{81}$ The problem, of course, was that the ban was motivated by animus against African Americans, just like same-sex marriage bans are motivated by animus toward homosexuals.

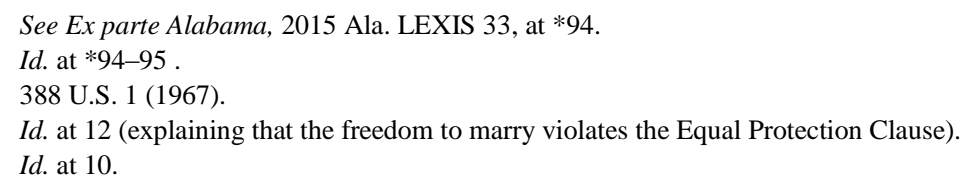


The Alabama Supreme Court attempted to distinguish Loving on the grounds that the decision retains the traditional definition of marriage, and "was not referring to an institution that formally recognized homosexual relationships." ${ }^{82}$ However, the question in Loving was whether bans on interracial marriage impermissibly discriminated on the basis of race, not whether the institution of marriage should be redefined. To distinguish Loving on that basis is to misapprehend its core holding: laws driven by prejudice or animus toward a particular group constitute invidious discrimination in violation of the Equal Protection Clause. Notwithstanding, the Alabama Supreme Court held that the highly deferential rational basis standard applied, and concluded that same-sex marriage bans were rationally related to the legitimate state objectives in procreation and child rearing.

The Court held that same-sex marriage could not be deemed a fundamental right under the Fourteenth Amendment's Due Process Clause because it was not "deeply rooted in the Nation's history and tradition." 83 The Court explained that heterosexual marriage "is a right of privacy older than the Bill of Rights - older than our political parties, older than our school system." $\$ 4$ Moreover, cases throughout history have considered marriage only in the context of opposite-sex couples, whereas same-sex marriage is a relatively "new notion" that was not permitted by any state until the twenty-first century. ${ }^{85}$

Simply put, "[m]en and women complement each other biologically and socially," 86 in that "the sexual union between man and woman (often) produces children." 87 For this reason, heterosexual marriage has "more to do with the morals and civilization of a people than any other institution" 88 and was created for the purpose of "produc[ing] ... upright, decent people ... [who] benefit from the love and care of both mother and father." 89 In doing so, heterosexual marriage "creates the family" and "provides the optimum environment for defining the responsibilities of parents and for raising children to be productive members of society." 90

82 Ex parte Alabama, 2015 Ala. LEXIS 33, at *99. The Court also relied on Baker v. Nelson, 191 N.W.2d 185 (Minn. 1971), which held that it was permissible to limit the definition of marriage to opposite-sex couples. The United States Supreme Court denied certiorari in that case for "want of a substantial federal question." See id., cert. denied, 409 U.S. 810 (1972).

83 Ex parte Alabama, 2015 Ala. LEXIS 33, at *100 (quoting Moore v. City of East Cleveland, 434 U.S. 494 (1977)).

84 Id. at $* 97$ (quoting Griswold v. Connecticut, 381 U.S. 479, 486 (1965)).

85 Id. at *99 (quoting Bostic v. Schaefer, 760 F.3d 352, 391 (4th Cir. 2014) (Niemeyer, J., dissenting); see also Goodridge v. Dep't of Pub. Health, 798 N.E.2d 941 (2003).

86 Ex parte Alabama, 2015 Ala. LEXIS 33, at *115.

87 Id.

88 Id. at *15 (quoting Maynard v. Hill, 125 U.S. 190, 205 (1888)).

$89 \quad I d$. at $* 17$.

$90 \quad I d$. at $* 116$. 
Consequently, permitting same-sex marriage would undermine "the fundamental unit of society," 91 which is to promote "stability and welfare ... [and] the general good of the public." ${ }^{92}$

The problem with the Court's reliance on the procreation and child rearing rationales is that these objectives are furthered, not undermined, by permitting same-sex marriage. In fact, both of these rationales have been thoroughly and convincingly debunked by a number of state and federal courts.

\section{a. The Procreation and Child Rearing Arguments Are Fallacious}

Numerous federal and state courts have rejected the argument that same-sex marriage bans further the state's interest in procreation and child rearing. For example, in Baskin v. Bogan, ${ }^{93}$ the Court of Appeals for the Seventh Circuit joined three other federal appeals courts and invalidated same-sex marriage bans in Indiana and Wisconsin. ${ }^{94}$ Writing for the majority, Judge Richard Posner held that the procreation argument lacked merit because the ability to procreate was never a prerequisite to receiving a marriage license. ${ }^{95}$ Judge Posner noted that, "if channeling procreative sex into marriage were the only reason that Indiana recognizes marriage, the state would not allow an infertile person to marry." 96 Posner stated as follows:

Indeed it would make marriage licenses expire when one of the spouses (fertile upon marriage) became infertile because of age or disease. The state treats married homosexuals as would-be "free riders" on heterosexual marriage, unreasonably reaping benefits intended by the state for fertile couples. But infertile couples are free riders too. Why are they allowed to reap the benefits accorded marriages of fertile couples, and homosexuals are not? ${ }^{97}$

Also, Indiana law permitted "marriages of close relatives for first cousins 65 or older - a population guaranteed to be infertile because women can't conceive at that age." 98 Judge Posner stated:

If the state's only interest in allowing marriage is to protect children, why has it gone out of its way to permit marriage of first cousins only after they are provably infertile? The state must think marriage valuable for something other than just procreation - that even non-procreative couples benefit from marriage. And among non-procreative couples, those that raise children, such as same-

$91 \quad$ Id. at $* 14$.

92 Id. at $* 17$.

93766 F.3d 648 (7th Cir. 2014); see also Bostic v. Schaefer, 760 F.3d 352 (4th Cir. 2014) (fundamental rights); Latta v. Otter, 771 F.3d 456 (9th Cir. 2014) (animus, fundamental rights, suspect classification); Bishop v. Smith, 760 F.3d 1070 (10th Cir. 2014) (fundamental rights); Kitchen v. Herbert, 755 F.3d 1193 (10th Cir. 2014) (fundamental rights).

94766 F.3d at 762.

$95 I d$. at 661 (noting that Indiana does not prevent an infertile person from marrying).

$96 \quad I d$.

97 Id.

$98 \quad I d$. at 662. 
sex couples with adopted children, gain more from marriage than those who do not raise children, such as elderly cousins; elderly persons rarely adopt. ${ }^{99}$

As a result, Indiana creates "an insidious form of discrimination: favoring first cousins, provided they are not of the same sex, over homosexuals."100 To be sure, "[e]lderly first cousins are permitted to marry because they can't produce children; homosexuals are forbidden to marry because they can't produce children."101 The infirmities in the state's argument revealed that the procreation argument was "impossible to take seriously." 102

Judge Posner also rejected the argument that, when opposite-sex couples have intercourse, a child may result, whereas same-sex couples can never produce children. ${ }^{103}$ Sterile and elderly couples are allowed to marry. As Posner stated, "[h] eterosexuals get drunk and pregnant, producing unwanted children; their reward is to be allowed to marry,"104 while "[h]omosexual couples do not produce unwanted children; their reward is to be denied the right to marry." operative question "is whether a society that allows same-sex marriage is less apt to procreate than a society that prohibits it. Almost certainly, the answer is "no.", 106

\section{b.Same-Sex Marriage Bans Harm, Rather than Protect, Children}

Judge Posner rejected the state's argument that marriage is intended to provide children with a stable and nurturing environment. Since Indiana expressly allows homosexual couples to adopt children, ${ }^{107}$ such bans actually undermine this interest because adopted children of same-sex couples will always be raised by unmarried couples:

If the fact that a child's parents are married enhances the child's prospects for a happy and successful life, as Indiana believes not without reason, this should be true whether the child's parents are natural or adoptive. The state's lawyers tell us that "the point of marriage's associated benefits and protections is to encourage child-rearing environments where parents care for their biological children in tandem." Why the qualifier "biological"? The state recognizes that family is about raising children and not just about producing them. It does not explain why the "point of marriage's associated benefits and protections" is inapplicable to a couple's adopted as distinct from biological children. ${ }^{108}$ 
Moreover, since "[m]arried homosexuals are more likely to want to adopt than unmarried ones if only because of the many state and federal benefits to which married couples are entitled," 109 the state actually had an interest in legalizing, not prohibiting, same-sex marriage. Thus, the "more willing adopters there are, not only the fewer children there will be in foster care or being raised by single mothers but also the fewer abortions there will be," 110 because some women mistakenly believe that their "only option is to kill [their] preborn child." 111 Furthermore, "[i]f marriage is better for children who are being brought up by their biological parents, it must be better for children who are being brought up by their adoptive parents." 112 Since Indiana permits joint adoption by homosexual couples, it should "want homosexual couples who adopt children ... to be married." 113 After all, if the state were truly interested in protecting children, it would strengthen all relationships where couples have children.

\section{Morality and Religion Are Not Valid State Interests}

In Lawrence v. Texas, ${ }^{114}$ the U.S. Supreme Court invalidated a Texas statute banning sodomy among same-sex couples only, holding that it violated the substantive guarantee of liberty and equal protection under the Fourteenth Amendment. ${ }^{115}$ Writing for the majority, Justice Anthony Kennedy held that, although "powerful voices ... condemn homosexual conduct as immoral," the state may not "enforce these views on the whole society through operation of the criminal law." 116 As Justice Kennedy stated, "[o]ur job is to define the liberty of all, not mandate our own moral code." 117 Justice Kennedy based his decision on principles of privacy and liberty, holding that "our laws and tradition afford constitutional protection to personal decisions relating to marriage, procreation, contraception, family relationships, child rearing, and education." 118

These matters, involving the most intimate and personal choices a person may make in a lifetime, choices central to personal dignity and autonomy, are central to the liberty protected by the Fourteenth Amendment. At the heart of liberty is the right to define one's own concept of existence, of meaning, of the universe, and of the mystery of human life. Beliefs about these matters could

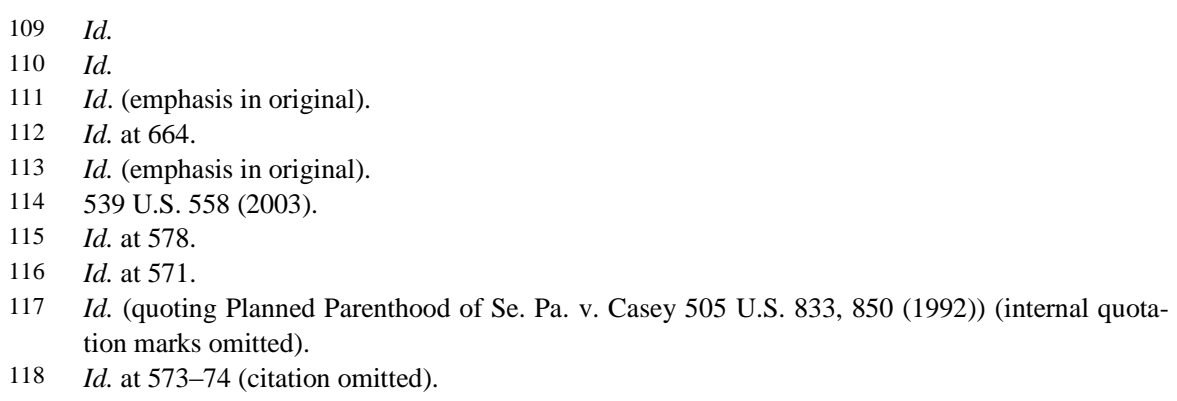


not define the attributes of personhood were they formed under compulsion of the State. ${ }^{119}$

Thus, "[p]ersons in a homosexual relationship may seek autonomy for these purposes, just as heterosexual persons do."120 Indeed, "[w]hen homosexual conduct is made criminal by the law of the State, that declaration in and of itself is an invitation to subject homosexual persons to discrimination both in the public and in the private spheres." 121 In a concurring opinion, Justice Sandra Day O'Connor premised her decision on equal protection principles, holding that the statute was invalid because it prohibited sodomy only among same-sex couples. ${ }^{122}$ This treats the same conduct differently based solely on the participants, thus making "homosexuals unequal in the eyes of the law by making particular conduct-and only that conduct-subject to criminal sanction." 123

Likewise, in United States v. Windsor, ${ }^{124}$ the Supreme Court invalidated Section Three of the Defense of Marriage Act, which limited the definition of marriage to opposite-sex couples and therefore withheld federal benefits from same-sex couples. ${ }^{125}$ Again writing for the majority, Justice Kennedy shifted his emphasis to equal protection principles, stating that "the Constitution's guarantee of equality 'must at the very least mean that a bare congressional desire to harm a politically unpopular group cannot' justify disparate treatment of that group." "126 "The avowed purpose and practical effect of the law here in question are to impose a disadvantage, a separate status, and so a stigma upon all who enter into same-sex marriages . . .."127 In so holding, Justice Kennedy reaffirmed the notion that "both moral disapproval of homosexuality, and a moral conviction that heterosexuality better comports with traditional (especially Judeo-Christian morality)" are both are impermissible bases upon which to justify discriminatory treatment. ${ }^{128}$

The Alabama Supreme Court distinguished Lawrence by holding that same-sex marriage involves "public state-governmental approval of their relationships," 129 whereas Lawrence merely stood for the proposition that the government does not have a legitimate interest in interfering with private, consensual conduct. Likewise, the Court distinguished Windsor on

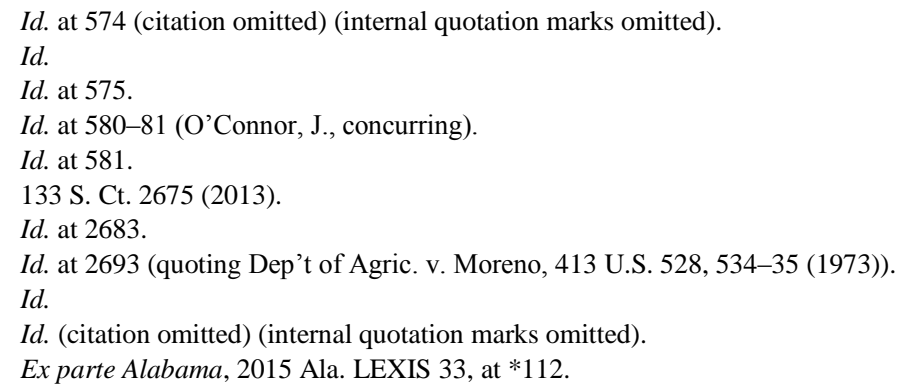


the ground that the U.S. Supreme Court's reliance on the "equal dignity" of homosexuals had no textual basis in the Constitution. ${ }^{130}$ Furthermore, Windsor's conclusion that married couples have more dignity under the law than unmarried couples was a moral, not legal, assessment, and "not contained in the Constitution." 131 Moreover, the Court's reliance on "equal dignity" was suspect because it was "not based on religion."132 One must wonder from this statement whether the Alabama Supreme Court would ignore a Supreme Court holding in favor of same-sex marriage for precisely these reasons.

Tellingly, the Alabama Supreme Court made no attempt to distinguish the myriad rulings from other state and federal courts that have rejected the procreation and child-rearing rationales. And for good reason: they cannot. The Sixth Circuit attempted to do so, but its reasoning was equally flawed.

\section{Same-Sex Marriage Should Not Be Left to the Democratic Process}

In DeBoer, the United States Court of Appeals for the Sixth Circuit became the first federal appeals court to hold that same-sex marriage bans did not violate the Constitution. Although the Court held that bans on samesex marriage furthered the rational state interest in procreation, ${ }^{133}$ it focused more on allowing the People to resolve this matter through the democratic process. With respect to procreation, the Sixth Circuit stated as follows:

By creating a status (marriage) and by subsidizing it (e.g., with tax-filing privileges and deductions), the States created an incentive for two people who procreate together to stay together for purposes of rearing offspring. That does not convict the States of irrationality, only of awareness of the biological reality that couples of the same sex do not have children in the same way as couples of opposite sexes and that couples of the same sex do not run the risk of unintended offspring. That explanation, still relevant today, suffices to allow the States to retain authority over an issue they have regulated from the beginning. ${ }^{134}$

$130 \quad$ Id. at $* 133-34$.

131 Id. at $* 139$. The Court also held that an open question existed regarding whether Windsor applied only to those states that had made the decision to recognize same-sex marriage. Id. at $* 144$. $132 \quad I d$. at $* 138$.

133 See DeBoer v. Snyder, 772 F.3d 388, 404 (6th Cir. 2014). The Court held that same-sex marriage bans were rationally-related to two governmental interests:

One starts from the premise that governments got into the business of defining marriage, and remain in the business of defining marriage, not to regulate love but to regulate sex, most especially the intended and unintended effects of male-female intercourse. Imagine a society without marriage. It does not take long to envision problems that might result from an absence of rules about how to handle the natural effects of male-female intercourse: children. May men and women follow their procreative urges wherever they take them? Who is responsible for the children that result? How many mates may an individual have? How does one decide which set of mates is responsible for which set of children? That we rarely think about these questions nowadays shows only how far we have come and how relatively stable our society is, not that States have no explanation for creating such rules in the first place. 
Given that there was at least a plausible basis to justify same-sex marriage bans, the best manner in which to resolve this issue was through the democratic process. In the Court's view, "if a federal court denies the people suffrage over an issue long thought to be within their power, they deserve an explanation ... [w]e, for our part, cannot find one."135 To be sure, "[n]ot one of the plaintiffs' theories, however, makes the case for constitutionalizing the definition of marriage and for removing the issue from the place it has been since the founding: in the hands of state voters." 136

What is more, the Fourteenth Amendment's broadly phrased language made it unwise to hold that same-sex marriage was not a right expressly contained in or inferable from the text. In the court's view, few would argue that the "people who adopted the Fourteenth Amendment understood it to require the States to change the definition of marriage."137 Since the definition of marriage has always been understood as the union of opposite sex couples, marriage laws should remain in force "until the democratic processes say they should stand no more." 138

Ultimately, the Sixth Circuit acknowledged that there are strong arguments in favor of recognizing same-sex marriage, but none were of sufficient importance to compel the conclusion that "one must look at this policy issue in just one way on pain of violating the Constitution." "139 In fact, one of the "key insights of federalism is that it permits laboratories of experimentation - accent on the plural-allowing one State to innovate one way, another State another, and a third State to assess the trial and error over time." 140

The Sixth Circuit's reasoning has superficial appeal, but on closer analysis fails because democracy does not give states or the people the right to enact or to continue enforcing laws that violate the Constitution, or that the U.S. Supreme Court is likely to deem unconstitutional. If the Sixth Circuit's decision were taken to its logical extreme, then states would be given sweeping power to enact laws provided that they could demonstrate more than "just one way" of viewing the law's constitutionality. This would turn constitutional law on its head because the question is not whether a law may be considered constitutional, but instead whether there is any basis upon which to conclude that, on its face or as applied, it is unconstitutional. In a stinging dissent, Judge Daughtrey wrote "[i]f we in the judiciary do not have the authority, and ... the responsibility, to right fundamental wrongs left excused by a majority of the electorate, our whole intricate, constitu-

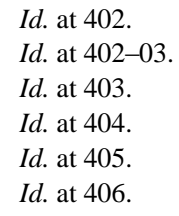


tional system of checks and balances, as well as the oaths to which we swore, prove to be nothing but shams." 141

For the reasons stated above, and for those stated by twenty-six state and federal courts, same-sex marriage bans violate the Equal Protection Clause. The state's interest in procreation is certainly a legitimate one, but same-sex marriage bans do not further, and same-sex marriage does not undermine, that interest. Giving same-sex couples the right to marry does not mean that heterosexual couples who have the ability and desire to procreate will suddenly decide to forego childbirth. In addition, permitting same-sex marriage will provide children of same-sex couples with a stable home and family environment that enjoys the same social and economic benefits as opposite-sex couples. In other words, as the Windsor Court held, same-sex couples will have equal dignity under the law, not be relegated to "second tier" marriages just as the separate but equal doctrine relegated African Americans to second-class citizenship. ${ }^{142}$

The dissenting opinion made precisely this point. Opponents of samesex marriage bans "ignore the destabilizing effect of its [marriage's] absence in the homes of tens of thousands of same-sex parents throughout the four states of the Sixth Circuit." 143 Knowing that these bans stigmatize homosexual relationships and invariably harm the children of those relationships, Alabama's continued enforcement of them reveals an underlying motive that has nothing to do with protecting the welfare of children: animus toward homosexuals.

\section{Roy Moore SHOUld Be Removed FRom the Alabama Supreme COURT AGAIN}

To be clear, people who oppose same-sex marriage bans often do so because of deeply held religious beliefs. They are not bad people and certainly should not be called bigots. What Chief Justice Moore is doing, however, is worthy of neither respect nor tolerance. Moore has done great damage to the rule of law, the Alabama Supreme Court, and the people of Alabama. And Chief Justice Moore has not been shy about expressing his view on homosexuality, particularly in his opinions as a member of the Alabama Supreme Court.

For example, in Ex parte H.H. ${ }^{144}$ decided one year before he was discharged from the bench, Moore wrote that the State has "the power to prohibit conduct with physical penalties, such as confinement and even execu-

141 Id. at 436-37 (Daughtrey, J., dissenting).

142 See Windsor, 134 S. Ct. at 2694 ("[DOMA] places same-sex couples in an unstable position of being in a second-tier marriage.").

143 DeBoer, 772 F. 3d at 422 (Daughtrey, J., dissenting).

144830 So. 2 d 21 (Ala. 2002). 
tion," and "must use that power to prevent the subversion of children toward this lifestyle [homosexuality], to not encourage a criminal lifestyle." 145 Moore went so far as to describe homosexuality as "an act of sexual misconduct punishable as a crime in Alabama, a crime against nature, an inherent evil, and an act so heinous that it defies one's ability to describe it." "146

The problem is not that Moore harbors these views, although many would find them to be patently offensive. The problem is that Moore's religious beliefs dominate his legal philosophy, his jurisprudence, and his conception of equal rights to such an extent that he is willing to create a constitutional crisis in the name of Christianity. Moore's words in Ex parte H.H. embrace precisely what the Alabama Supreme Court found problematic in Windsor: they represent moral, not legal judgments, and they reflect prejudice, not principle.

\section{CONCLUSION}

In his dissenting opinion, Justice Shaw refused to address the issue of whether the district court's decision was correct. ${ }^{147}$ In doing so, Justice Shaw understood that personal ideology should not trump a court's obligation to remain faithful to the rule of law and to the orderly administration of justice. That is precisely where Roy Moore - and the rest of the Alabama Supreme Court - got it wrong. They allowed their personal beliefs - and animus toward homosexuals - to engineer a startlingly dishonest interpretation of the law and a disheartening attack against same-sex couples.

Judge Shaw criticized the majority for its manipulation of the law and for the "unforeseen consequences [that will occur] in future cases." 148 The immediate consequences for same-sex couples are as troubling as the unforeseen consequences to the integrity of our judicial system. Same-sex marriage does not harm children, the institution of marriage, or oppositesex couples' ability to procreate. It reflects the basic principle that, absent legitimate government interests, every citizen is entitled to be treated equally under the law and to fully enjoy the rights and protections enumerated in the Constitution. When court rulings compromise that core value, they threaten the liberty and equal dignity guaranteed to every citizen. Put simply, "[t]rue freedom requires the rule of law and justice, and a judicial system in which the rights of some are not secured by the denial of rights to

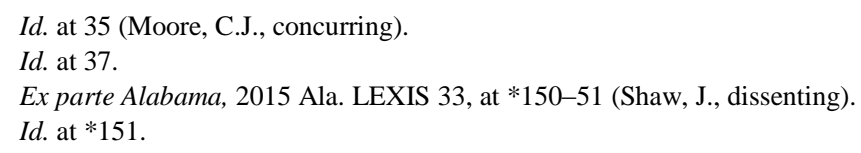


others." 149 For that reason, the United States Supreme Court should hold that same-sex marriage bans violate the Equal Protection Clause, and put another nail in the coffin of discrimination and inequality.

149 Chief Rabbi Lord Sacks, Passover Tells Us: Treat Your Children Well (Apr. 17, 2011), available at http://www.huffingtonpost.com/chief-rabbi-lord-sacks/passover-message-forhuff_b_849623.html. 